\title{
Analysis and Solution of Common Problems in Construction Project Audit
}

\author{
Fang Wang \\ ningxia construction vocational and technical college \\ (NINGXIA ,CHINA 750001)
}

Keywords: Construction project audit; Supervision function; Problem; Solution suggestion

\begin{abstract}
The construction project audit function is to make the construction more standardized, so the construction project audit is to strengthen the audit and supervision functions of the economic, scientific and reasonable construction project audit which is conducive to improve efficiency in the use of funds. At this stage, there are some urgent problems to be solved in the construction project audit. In this paper, the author has carried on the analysis in the light of many years work experience, and it has proposed several solution measures.

Construction project audit has certain economic supervision function, as an important form of basic economic activities of the construction supervision, it is the supervision of the construction unit of the investment process, and it can evaluate the scientific and impartial, formulate detailed audit report. Through the construction project audit, the construction project cost can be truly reflected, so that the construction unit investment interests have the important guarantee. However, due to the impact of various factors in the actual work, it has a serious impact on the construction project audit. In order to make full use of the economic supervision function of the construction project audit and reduce the investment loss of the construction units, the author analyzes the existing problems and puts forward some solutions.
\end{abstract}

\section{Analysis of Problems Existing in Construction Project Audit}

The construction project is a systematic and complicated project with many uncertain factors, in order to ensure the construction unit investment benefit, the auditor must take timely and effective measures to control the impact of these uncertain factors to a minimum to make the construction project audit work smoothly. At present, the following problems exist in the construction project audit:

Lacking of perfect audit management system. Construction projects include decision-making stage, design stage, bidding stage, construction stage, completion settlement phase, and final accounts and project evaluation phase. Because the construction project audit system is not perfect, it is difficult to supervise the whole construction project effectively. In general, the construction project means the construction units, construction units and supervision units "three-in-one" management system, in the actual construction engineering supervision, prone to problems caused by the powers and responsibilities are not clear leading to construction, supervision, cost management, and auditing of multiple link cannot be efficiently linked. There are still some construction projects, and no feasibility analysis, and even the lack of investment funds with too blind construction, which reflects the current construction project audit in urgent need of sound management system.

Lacking of standardized bidding methods. In order to reduce the "black box" operation in the construction industry, China has formulated an investment mechanism suited to the market economy to minimize the investment in construction funds and ensure the benefits of construction units. But in the actual construction project, due to the lack of a correct understanding of the whole process cost of construction project, some key audit institutions will work on the stage of completion, not on the other stages in the audit work given attention resulting in a serious waste of money. Especially in the bidding stage of construction projects, because of the lack of standardized bidding methods, the bidding process is prone to irregularities.For example, in the actual bidding process, there should be tender but did having no move, especially in the process of tendering for 
survey and design, building materials procurement and supervision of enterprises are easy to form confusion; there are some bidding companies for advertising in the regular online media or in accordance with the relevant laws rules, or tender is not scientific with extensive content; and in the pre-qualification tender, audit work loss form is related regulations and even ignore pre-trial, which is likely to lead to some aspects that do not comply with the relevant standards for construction enterprises to participate in the construction project; in addition, to some construction projects in the bidding process, there is not clearly important the data leading to temporary pricing more projects, this will give the final buried great hidden danger. Therefore, in the bidding stage of construction projects, the lack of standardized bidding methods will inevitably affect the smooth development of the late audit work.

Ignoring the audit management of construction process. In the construction project audit process, because some audit institutions focuses on completion of settlement stage ignoring the tracking supervision of the construction process, on the one hand, the influence of the audit work carried out smoothly, the construction process is an important stage of the project cost that have a direct impact on the economic benefits of construction unit ignoring the audit the management of the construction process that will inevitably lead to some unnecessary waste of money, and even prone to lead to violations of the construction process. For example, in the construction process, construction enterprises do not employ supervision units or supervision units will not seriously implement their regulatory functions, some construction enterprises change project content, and some construction enterprise project change content without specification or without timely visa visa.These problems will directly affect the authenticity and validity of the design change having a great impact on the construction project construction period; in the field of building materials, in order to reduce costs, or purchasing personnel for their own procurement of substandard materials or no certification materials, and supervision personnel having no implementation of regulatory functions once these building materials used will bring great risks to the overall quality of construction projects in the construction process of the inevitable. In addition, the problem of timely measurement, or centralized metering and repeated measurement of construction projects have occurred frequently, which has led to inaccurate measurements and will lead to certain economic losses.

Problems existing in the process of completion settlement. In the process of completion of the project settlement, audit institutions and auditors often fail to find problems in time and formulate corresponding measures, which cause great economic losses to the construction units. For example, some construction enterprises use contract gap to inflate cost of the project, the main reason of this problem lies in the lack of attention to contract construction units and construction units, only have the construction schedule and quality control. On the signing of the contract, the contract is on the engineering price and did not specify found in the stage of completion process. This inflated project cost for construction enterprise will bring the convenience, if the situation is serious, it is a great loss for the construction unit;Engineering errors problem will affect the completion of the settlement smoothly, such as the unit of measurement is not consistent, the decimal point dislocation caused by these small details of the loss that is immeasurable; applying the quota settlement problems without comprehensive explanation for the high quota or repeated application of quota. These problems will have a certain impact on the completion of the settlement. In short, in the completion of the settlement process, there are many uncertain factors affecting the settlement work smoothly, and these problems need auditors attention and formulate measures to reduce the economic losses of the construction unit.

\section{Suggestions on Solving the Problems Existing in Construction Project Audit}

Through the above analysis on the existing problems in the construction project audit,it can clear prove the importance of audit work for construction projects carried out smoothly, and to strengthen the audit worksolving the existing problems timely in the audit work is where the healthy development of the construction industry, and aiming at the above problems, the author puts forward the following suggestions: 
Establishing and perfecting the system of engineering audit supervision. In order to ensure the smooth development of construction project audit, it must establish a sound audit supervision system. For example, the construction enterprise can formulate supervision and supervision mechanism, strengthen the implementation of supervision function, and ensure the impartiality of supervision. At the same time, supervision personnel need to track the whole process of construction to ensure the quality and safety of each link; The establishment of the internal audit supervision mechanism can strengthen the implementation of the economic supervision function of auditors. Prior to the establishment of the construction project, the supervisors need to test the feasibility of the project and assess the relevant enterprises to ensure that the qualifications and credibility of each enterprise meeting the requirements. In the process of project construction, the auditors also need timely inspection and supervision to ensure the smooth development of the construction process and quality standards; establishing a settlement supervision mechanism will improve the audit personnel's working efficiency and settlement efficiency, reduce unnecessary trouble in the process of completion of the settlement, but also can improve the accuracy of settlement data. Strengthening audit investigation and evidence collection

The construction project audit and audit staff should be based on the design drawings, visa, budget and settlement quota and the corresponding policy to carry out the audit work, in practical work, the audit needs to combine the data of the construction project audit investigation and evidence. However, some construction enterprises often have such problems as designing false drawings, excessive budget or falsifying engineering quantities, which results in the failure of audit institutions and auditors to obtain audit data accurately. In order to reduce the occurrence of these circumstances, the audit should do the audit investigation and evidence collection work, and it is necessary to conduct field surveys tracking the construction process to fully understand the construction situation, according to the price of building materials, it can be investigated for the construction market, price volatility and the situation of building materials to ensure the accuracy of audit evidence. It is also an important guarantee for the construction of enterprise investment interests.. Strengthening the audit of the contract

The audit and audit personnel need to strengthen the construction contract audit work, the responsibilities of both parties of the contract being clear to avoid confusion causing unnecessary trouble and losses to ensure the smooth development of the construction of the construction project. At the same time, audit institutions and auditors need to ensure the contents of the contract normative, comprehensive and applicable, the terms of the contract should be complete and prudent. For the cost of the audit should be serious, strict, and avoid construction enterprises wantonly change costs. Only when the contents of the contract are standardized, comprehensive and prudent, the law can be carried out in case of disputes, and it is also an important guarantee for the interests of both sides of the contract.

Establishing strict procedure for project change audit. In the construction project, it will inevitably cause some uncertain factors to design changes that will exceed the budget, in order to reduce the design change bring disputes to the construction units and construction units, it requires the audit and audit staff on the budget design changing produced strictly audit. So in the construction project, it should make strict change on audit procedures to ensure audit staff strictly examine the design change, and do a good job of project design changes and related procedures to change the scale of the audit work and give full play to the supervision of audit staff and audit function to improve audit efficiency and the quality with improving the comprehensive quality of auditors, but also protecting the interests of the construction unit investment.

\section{Conclusion}

Construction project audit is a relatively complex work, which is an important guarantee for the investment interests of construction units. Only scientific and rigorous audit work can play the role of supervision and management in the whole process of construction projects to reduce the occurrence of improper or illegal acts and protect the economic interests of the parties involved in construction projects. So the audit and audit staff should be fully aware of a series of problems in 
the work of audit by improving the corresponding mechanism and doing the investigation and evidence collection, contract review, change audit work to improve the quality and efficiency of audit.

\section{Reference}

[1] Xiuzhen Ding.Analysis and solution of common problems in construction project audit[J].Research on Modern State-owned Enterprise.2016 (20) : 214-215.

[2] Linghui Ma.Problems and Countermeasures of final accounts audit of construction projects[J].Architectural Engineering Technology and Design,2016,(6):927-927.

[3] Yong Zheng.Several legal issues about construction cost audit in construction project audit--taking the Interim Measures for the settlement of construction costs as the basis of analysis[J].Auditing and Financing,2013,(7):16-18. 